\title{
The association study of polymorphic variants of hypothalamic-pituitary-adrenal system genes (AVPR1B, OXTR) and aggressive behavior manifestation: a focus on social environment
}

\author{
Anastasiya V. Kazantseva ${ }^{1,2}$ (D), Yuliya D. Davydova ${ }^{1}$, Renata F. Enikeeva ${ }^{1}$, \\ Rinat G. Valinurov ${ }^{3}$, Anna E. Gareeva ${ }^{1}{ }^{\mathbb{D}}$, Nataliya N. Khusnutdinova ${ }^{1}$ (D), \\ Elza K. Khusnutdinova ${ }^{1}$ (D) \\ ${ }^{1}$ Ufa Federal Research Centre of the Russian Academy of Sciences, \\ 71 Oktyabrya Ave., Ufa, 450054, Russia \\ ${ }^{2}$ Ufa State Petroleum Technological University, \\ 1 Kosmonavtov St., Ufa, 450064, Russia \\ ${ }^{3}$ Bashkir State Medical University, \\ 3 Lenin St., Ufa, 450008, Russia \\ Corresponding author: Anastasiya V. Kazantseva (Kazantsa@mail.ru)
}

\begin{abstract}
Background: Aggressive behavior (AB) represents an important social problem, which results in significant costs for the society. A significant role in developing aggression is suggested to be mediated by molecular mechanisms related to the functioning of oxytocin $(O X T R)$ and arginine vasopressin receptor $(A V P R 1 B)$ genes involved in the regulation of social behavior. On the other hand, a specificity of environmental factors affecting an individual at various stages of development may modulate the molecular processes, especially at gene expression level, thus affecting human's ability to self-control and resulting in $\mathrm{AB}$ manifestation. The aim of the study: Considering a multifactorial nature of developing aggression, the present study is aimed to estimate both the genetic- and haplotype-based effects of the OXTR and $A V P R I B$ genes and gene-by-environment interactions in developing AB. Materials and methods: The genotyping of the $O X T R$ (rs2228485, rs53576) and AVPR1B (rs33911258) gene variants was conducted via PCR with fluorescent detection in 189 criminal offenders (7\% women) from the Republic of Bashkortostan, who committed murders, and the control group ( $\mathrm{N}=254,12 \%$ women) corresponding to the group of criminal offenders by ethnicity and age. Statistical analysis was performed via logistic regression with correction for multiple comparisons (PLINK v.1.09). Results: As a result of statistical analysis the association of rs2228485 $A$-allele and $A G$ haplotype (rs2228485 and rs53576) in the OXTR gene with an enhanced risk for developing $\mathrm{AB}$ was observed. In addition, we demonstrated a modulating effect of such environmental factors as the presence of severe somatic diseases, alcohol addiction, fa-
\end{abstract}


milial history of psychopathologies, income and education level. Moreover, the effect of rs33911258 $G$-allele in the $A V P R 1 B$ gene on AB was observed. Conclusion: The data obtained evidence that the examined variants in the AVPRIB and OXTR genes in combination with specific environmental factors may affect neuronal systems functioning, thus resulting in the manifestation of antisocial behavior.

Keywords: antisocial behavior; HPA axis; oxytocin; arginine vasopressin; association analysis; callous-unemotional traits

For citation: Kazantseva AV, Davydova YD, Enikeeva RF, et al. The association study of polymorphic variants of hypothalamic-pituitary-adrenal system genes (AVPR1B, OXTR) and aggressive behavior manifestation: a focus on social environment. Research Results in Biomedicine. 2021;7(3):232-244. DOI: 10.18413/26586533-2021-7-3-0-3

Background. Aggressive behavior $(\mathrm{AB})$ represents a complex phenomenon considered as an action directed toward causing harm or damage to another living being, who contradicts to such treatment [1]. $\mathrm{AB}$ is an important social problem causing significant costs for the society. In particular, according to the data of the Ministry of Internal Affairs of the Russian Federation, in 2020 more than 2 million crimes were committed in the Russian Federation, of which 109.8 and 453.3 thousand cases corresponded to grave and gravest crimes (murder and intentional infliction of serious harm to health), respectively [2]. The mechanisms underlying the development of $\mathrm{AB}$ are complex, while genetic and epigenetic factors are playing a significant role (the coefficient of inheritance of aggression is about $0.65[1,3])$, therefore they have been extensively studied in the contemporary research.

Together with the classical pathways of monoaminergic neurotransmission, the genes involved in the regulation of the hypothalamic-pituitary-adrenal (HPA) system, including the genes encoding arginine vasopressin (AVPR1A, AVPR1B) and oxytocin (OXTR) receptors, are of interest in the study of genetic liability to developing antisocial and aggressive behavior. The role of neuropeptides oxytocin and arginine vasopressin in regulation of social behavior, social cognition, individual stress response, depression and callous-unemotional traits has been reported to date $[4,5]$. In turn, impaired functioning of oxytocin and arginine-vasopressin $1 \mathrm{~b}[5,6]$ and their receptors was demonstrated in animal models of exaggerated aggressive behavior, while a reduced oxytocin level was a predictor of aggression in humans [7]. The similarity in the amino acid sequence between oxytocin and arginine-vasopressin promotes differences in the affinity to their receptors [8], thus providing the resemblance in the processes that both neuropeptides modulate.

Despite its location in the intronic region of the OXTR gene, rs53576 remains one of the most examined SNPs in this gene to date. Functional studies related the presence of rs53576 $G$-allele to enhanced hippocampal neurogenesis in males [9], higher expression of the OXTR gene due to its reduced methylation [10] and, hence, to increased receptor sensitivity to oxytocin [11]. Multiple findings were reported on the effect of this SNP on developing psychiatric disorders [12] and prosocial behavior $[11,13]$ including socioemotional information processing [14]. Considering a negative correlation between oxytocin level in cerebrospinal fluid (CSF) and individual history of suicide attempts and aggression [15], it was suggested that enhanced OXTR gene expression related to rs53576 Gallele could be a predictor of a lower risk for manifesting antisocial behavior due to a compensatory effect of low oxytocin level [11].

However, the development of antisocial behavior is a very complex process, which is also attributed to the fine regulation of gene expression through epigenetic changes affected by social and adverse environment in ontogenesis [3]. Therefore, one of the prominent 
functional SNPs candidate in the OXTR gene is rs2228485 (c.171C>T, p.Asn57) due to its location in one of the $\mathrm{CpG}$ islands (according to Methyl Primer Express Software v.1.0, Applied Biosystems). In particular, this SNP may be involved in the regulation of $O X T R$ gene expression via allele-specific differential methylation. According to our recent study [16], OXTR rs2228485 $G$-allele and $G G G$ haplotype (rs53576, rs2228485, and rs237911) was statistically more frequent in mentally healthy students from the Republic of Bashkortostan with a decreased aggression score (measured with the Buss-Perry Aggression Questionnaire), and this effect was ethnicity-specific. Therefore, we hypothesize that the same direction of association (i.e. reduced frequency of $\mathrm{rs} 53576$ and $\mathrm{rs} 2228485 G$ alleles) has to be observed in individuals with violent criminal behavior.

Interesting findings have been recently demonstrated by Staes et al. (2020), who reported a species-specific existence of rs2228485 $A$-allele between two close great apes' species [17]. The $A$-allele became fixed in chimpanzees (Pan paniscus) but only ancestral G-allele is present in bonobos (Pan troglodytes). The authors suggested that this observation might be attributed to the differences in theory of mind and social causality between the Pan species. From the evolutionary perspective rs2228485 $A$-allele was fixed in chimpanzees due to selection of this allele, which probably facilitated stronger male-male bonding in this species [17]. Therefore, we suggest that OXTR rs2228485 $A$-allele may be attributed to male aggressive behavior in humans too.

Association studies indicated the effect of polymorphic variants rs53576 and rs2228485 in the OXTR [4, 12, 18-22] and $A V P R 1 B$ [23] genes on antisocial and aggressive behavior and callous-unemotional traits. However, a recently published meta-analysis, which was based on 15 samples in 12 studies $(\mathrm{N}=12,236)$ examining the association of 8 different $O X T R$ SNPs on antisocial behavior, confirmed the effect of rs237887 and examined phenotype only, while the effect of the most studied rs53576 on aggression-related traits failed to be confirmed [24]. However, the authors indicated the high levels of heterogeneity between the studies and were concerned on the quality control, thus providing a rationale to conduct the study with more severe antisocial behavior.

Recent neurobiological research indicated the existence of genotype-related differences in brain functional connectivity and hippocampal- [25] and amygdala-related [26] manifestation of social behavior. To be more precise, a male-specific effect of functional rs53576 in the OXTR gene was observed on the disruption of integrity in a large-scale intrinsic brain and altered functional connectivity in brain regions, which was profound in $A A$-homozygote compared with $G$-allele carriers [27]. In addition, adolescent girls, who reported higher childhood adversity level and bearing rs53576 $A A$-genotype, had a reduced left hippocampal volumes compared to those with minimal adversity [25]. In line, rs53576 $G G$-homozygous boys had larger left hippocampal volumes compared to A-allele carriers [9]. Moreover, the presence of callousunemotional traits in childhood was shown to interact with the level of OXTR methylation, thus affecting brain systems involved in decoding and integrating socio-affective information and causing the development of conductive disorder [28]. These observations provide a rationale for the examination of OXTR genotype with respect to different aspects of social adversity.

The AVPR1B is known to mediate the secretion of the adrenocorticotropic hormone, which represents an important component of the hypothalamic-pituitary-adrenal (HPA) axis, thus explaining its relation to adaptive and prosocial behaviors, as well as aggressionrelated traits [8]. According to evolutionary research, specific sites in the $A V P R I B$ gene were under positive selection related to domestication [29] - a process involving the accumulation of prosocial traits. In addition, functional research indicated the relation of a reduced level of aggression in AVPRIb knockout mice [6]. Recent findings indicated the association between an impaired social behavior and altered expression of $A V P R I B$ 
and OXTR genes in murine brain as a response to antibiotic treatment [30]. According to association studies, SNPs in the $A V P R 1 B$ were implicated in individual differences in emotional empathy and prosociality [31], depressive [32] and aggressive traits in humans [16] and in rhesus macaques [33]. Considering these observations, the analysis of $A V P R 1 B$ gene variants with respect to antisocial behavior is of high relevance.

Despite a recent trend toward the study of certain environmental conditions, mainly including stressful life events [34], specificity of childhood rearing [35, 36], childhood abuse [37], peers' delinquency [18] and socioeconomic status [20] separately, which can affect molecular-genetic mechanisms underlying empathy, prosocial and aggressive behavior, the data on the other potential confounders is scarce. Moreover, the number of studies examining gene-by-environment interactions in severe types of antisocial behavior (i.e. murders) is limited, thus pointing to the necessity to analyze the potential role of genetic predisposition in such group of criminal offenders.

The aim of the study. Considering multiple contradictory findings reporting the effect of different allelic variants in the OXTR gene on developing antisocial and conduct behavior, which is also mediated by specific environment, we aimed to clarify the accumulation of certain alleles of promising variants in the OXTR (rs53576 and rs2228485) and $A V P R 1 B$ (rs33911258) genes in individuals with violent criminal behavior. Moreover, we sought to evaluate both the main effect of polymorphic variants and haplotypes of the $O X T R$ and $A V P R I B$ genes on manifesting exaggerated antisocial traits in the total sample of offenders and in the groups stratified by adverse/non-adverse environment. Third, we attempted to detect a modulating effect of environmental parameters on SNP-based genetic associations under gene-by-environment interaction models.

Materials and methods. The study sample comprised of 189 criminal offenders (7\% women) of different ethnicity (89 Russians, 63 Tatars and 34 Bashkirs) (mean age
$41.53 \pm 14.41$ years), who underwent a forensic psychiatric examination in a criminal case related to the commission of serious crimes (murders) in the Republican Clinical Psychiatric Hospital (Ufa, Russia). Criminal offenders were recognized by the Court as sane persons and were sent to serve their sentences in places of derention. A control group consisted of 254 mentally healthy individuals (12\% women), who corresponded to the group of criminal offenders by age (mean age $37.10 \pm$ 18.38 years), sex and ethnic background (117 Russians, 91 Tatars and 45 Bashkirs), were not registered in the psychiatric database before and had no family history of mental disorders. All the enrolled individuals signed an informed consent for the participation in the study after they were acquainted with experimental procedures. The present study was approved by the local bioethical committee at the Institute of Biochemistry and Genetics (Ufa, Russia).

DNA was extracted from the peripheral blood leukocytes according to the phenolchloroform extraction approach. PCR with end-point KASP fluorescent detection (MaxMedical, Moscow, Russia) on CFX96 DNAAnalyzer (BioRad, USA) was used for the genotyping of the OXTR (rs2228485, rs53576) and AVPR1B (rs33911258) gene variants.

Statistical analysis included the correspondence of the observed allele and genotype frequencies to the expected HardWeinberg equilibrium. The main effect of gene variants and haplotypes in the total sample, as well as in groups stratified by the environmental parameters on an individual risk for developing $\mathrm{AB}$ was carried out under additive, dominant, and recessive models of logistic regression (PLINK v.1.09). The estimation of the effect of gene-by-environment interaction on manifesting antisocial behavior was based on the inclusion of examined gene SNPs and environmental parameters (sex, ethnicity, family structure, childhood adversity, smoking, alcohol addiction, income level, birth order, education level, the presence of severe somatic disorders and familial history of psychopathologies) as predictors in multi- 
ple regression models, while the presence/absence of $\mathrm{AB}$ served as an outcome. False discovery rate (FDR) procedure and 10000 permutation approach were used to control for multiple comparisons (PLINK v.1.09).
Results and discussion. The distribution of allele and genotype frequencies of the OXTR (rs2228485, rs53576), AVPR1B (rs33911258) gene SNPs corresponded to the Hardy-Weinberg equilibrium (Table 1).

Table 1

Genotype frequencies and the Hardy-Weinberg equilibrium in studied groups

\begin{tabular}{|c|c|c|c|c|c|c|c|}
\hline Gene & SNP & Minor/major allele & Group & \multicolumn{3}{|c|}{ Genotype frequency } & $\mathbf{P}_{\text {HWE }}$ \\
\hline \multirow{3}{*}{$A V P R 1 B$} & \multirow{3}{*}{ rs33911258 } & \multirow{3}{*}{$\mathrm{G} / \mathrm{A}$} & In total & 0.009 & 0.252 & 0.739 & 0.238 \\
\hline & & & $\mathrm{AB}$ & - & 0.257 & 0.743 & 0.078 \\
\hline & & & Control & 0.018 & 0.247 & 0.735 & 1 \\
\hline \multirow{6}{*}{ OXTR } & \multirow{3}{*}{ rs53576 } & \multirow{3}{*}{$\mathrm{A} / \mathrm{G}$} & In total & 0.199 & 0.490 & 0.311 & 0.912 \\
\hline & & & $\mathrm{AB}$ & 0.192 & 0.485 & 0.323 & 0.875 \\
\hline & & & Control & 0.206 & 0.494 & 0.300 & 1 \\
\hline & \multirow{3}{*}{ rs2228485 } & \multirow{3}{*}{$\mathrm{G} / \mathrm{A}$} & In total & 0.042 & 0.335 & 0.623 & 1 \\
\hline & & & $\mathrm{AB}$ & 0.036 & 0.287 & 0.676 & 0.792 \\
\hline & & & Control & 0.047 & 0.382 & 0.571 & 0.678 \\
\hline
\end{tabular}

Note: $\mathrm{P}_{\mathrm{HWE}}-\mathrm{P}$-value for Hardy-Weinberg equilibrium.

According to the results obtained under a series of multiple logistic regression analyses, we observed a statistically significant effect of several environmental parameters with a risk for manifesting antisocial behavior, which included the presence of severe somatic diseases $(\beta=1.086, \mathrm{P}<0.001)$, low education level $(\beta=2.160, \mathrm{P}<0.001)$, smoking $(\beta=1.105, \mathrm{P}<0.001)$, birth order $(\beta=0.640, P=0.008)$, sex (men, $\beta=1.228$, $\mathrm{P}=0.001)$, and age $(\beta=-2.149, \mathrm{P}<0.001)$. At the same time, ethnic background, aggression type, family history of psychopathologies, alcohol addiction, income level, childhood adversity, and family structure demonstrated no significant impact on increased aggression (Table 2). Accordingly, we included age, sex and ethnicity as covariates in subsequent logistic regression models.

Since there were no statistically significant differences in allele and genotype frequencies distribution of the examined SNPs between individuals of different ethnic subgroups $(\mathrm{P}>0.05)$, we conducted the association analysis in total sample controlling for age, sex and ethnicity in logistic regression models. As a result of statistical testing of
SNPs effect on manifesting $\mathrm{AB}$ under various models (additive, dominant, and recessive), we detected a reduced frequency of OXTR rs2228485 $G$-allele and $G G$-genotype $(\mathrm{P}=$ $0.045 ;$ OR $=0.63)$ as well as $A V P R 1 B$ rs33911258 $G$-allele $(\mathrm{P}=0.004 ; \mathrm{OR}=0.95)$ in a group of criminal offenders compared to the population control group in the total sample. This effect was also exaggerated in the subsample of criminal offenders stratified by environmental parameters: in those with severe somatic disorders $(\mathrm{P}=0.035 ; \mathrm{OR}=$ $0.56)$, alcohol addiction $(\mathrm{P}=0.034 ; \mathrm{OR}=$ $0.61)$, familial history of psychopathologies $(\mathrm{P}=0.025 ; \mathrm{OR}=0.52)$, and high income level $(\mathrm{P}=0.023 ; \mathrm{OR}=0.32)$ (Table 2). It should be mentioned, that a trend of a lower frequency of $O X T R$ rs2228485 GG-genotype was also evident in a group of individuals with antisocial behavior, who were characterized by high education level $(\mathrm{P}=0.076 ; \mathrm{OR}=0.57)$, absence of lifetime smoking $(\mathrm{P}=0.072$; $\mathrm{OR}=$ $0.53)$ and childhood adversity $(\mathrm{P}=0.081$; OR $=0.664)$, reared in a complete family $(\mathrm{P}=$ $0.080 ; \mathrm{OR}=0.656)$, and being third children in a family $(\mathrm{P}=0.074$; $\mathrm{OR}=0.56)$ compared to population control (Table 2). 
Table 2

Characteristics of the studied sample and logistic regression in various groups

\begin{tabular}{|c|c|c|c|c|c|}
\hline \multirow{3}{*}{$\begin{array}{c}\text { Environmental } \\
\text { parameter }\end{array}$} & \multirow{3}{*}{$\beta$ (P-value) } & \multirow{3}{*}{ Group } & \multirow{3}{*}{$\begin{array}{c}\text { AVPR1B } \\
\text { rs33911258 } \\
\text { C } 14 * *\end{array}$} & \multicolumn{2}{|c|}{ OXTR } \\
\hline & & & & rs53576 & rs2228485 \\
\hline & & & & $\mathbf{A} / \mathbf{G} * *$ & $\mathbf{G} / \mathbf{A}^{* *}$ \\
\hline \multirow{2}{*}{ Sex } & \multirow{2}{*}{$1,228(0.001)$} & $\begin{array}{c}\text { Men } \\
(\mathrm{N}=176)\end{array}$ & $\begin{array}{c}0.666 \\
(1.124)\end{array}$ & $\begin{array}{c}0.290 \\
(0.761)\end{array}$ & $\begin{array}{c}0.15 \\
(0.703)\end{array}$ \\
\hline & & $\begin{array}{l}\text { Women } \\
(\mathrm{N}=13)\end{array}$ & - & - & - \\
\hline \multirow{3}{*}{ Ethnicity } & \multirow{3}{*}{$-0.008(0.957)$} & $\begin{array}{l}\text { Russians } \\
(\mathrm{N}=89)\end{array}$ & $\begin{array}{c}0.706 \\
(1.148)\end{array}$ & $\begin{array}{c}0.760 \\
(1.075)\end{array}$ & $\begin{array}{c}0.170 \\
(0.667)\end{array}$ \\
\hline & & $\begin{array}{c}\text { Tatars } \\
(\mathrm{N}=63)\end{array}$ & $\begin{array}{c}0.591 \\
(0.791) \\
\end{array}$ & $\begin{array}{c}0.132 \\
(0.534) \\
\end{array}$ & $\begin{array}{c}0.415 \\
(0.725) \\
\end{array}$ \\
\hline & & $\begin{array}{l}\text { Bashkirs } \\
(\mathrm{N}=34)\end{array}$ & $\begin{array}{c}0.476 \\
(0.690)\end{array}$ & $\begin{array}{c}0.527 \\
(1.255)\end{array}$ & $\begin{array}{c}0.195 \\
(0.550)\end{array}$ \\
\hline \multirow{2}{*}{ Aggression type } & \multirow{2}{*}{$23.854(0.994)$} & $\begin{array}{l}\text { Proactive } \\
(\mathrm{N}=175)\end{array}$ & $\begin{array}{c}0.693 \\
(0.909) \\
\end{array}$ & $\begin{array}{c}0.673 \\
(0.935) \\
\end{array}$ & $\begin{array}{c}0.121 \\
(0.736) \\
\end{array}$ \\
\hline & & $\begin{array}{l}\text { Reactive } \\
(\mathrm{N}=14)\end{array}$ & - & - & - \\
\hline \multirow{2}{*}{ Somatic diseases } & \multirow{2}{*}{$1.086(<0.001)$} & $\begin{array}{c}\text { Yes } \\
(\mathrm{N}=117)\end{array}$ & $\begin{array}{c}0.932 \\
(0.976) \\
\end{array}$ & $\begin{array}{c}1 \\
(1)\end{array}$ & $\begin{array}{l}0.035 * \\
(0.569) \\
\end{array}$ \\
\hline & & $\begin{array}{c}\text { No } \\
(\mathrm{N}=72)\end{array}$ & $\begin{array}{c}0.324 \\
(0.716) \\
\end{array}$ & $\begin{array}{c}0.194 \\
(0.753) \\
\end{array}$ & $\begin{array}{c}0.566 \\
(0.861) \\
\end{array}$ \\
\hline \multirow{2}{*}{ Education level } & \multirow{2}{*}{$-2.160(<0.001)$} & $\begin{array}{c}\text { High } \\
(\mathrm{N}=76)\end{array}$ & $\begin{array}{c}0.900 \\
(1.042) \\
\end{array}$ & $\begin{array}{c}0.379 \\
(1.339) \\
\end{array}$ & $\begin{array}{l}0.076^{*} \\
(0.577) \\
\end{array}$ \\
\hline & & $\begin{array}{c}\text { Low } \\
(\mathrm{N}=113)\end{array}$ & $\begin{array}{c}0.615 \\
(0.871) \\
\end{array}$ & $\begin{array}{c}0.528 \\
(0.894) \\
\end{array}$ & $\begin{array}{c}0.162 \\
(0.729) \\
\end{array}$ \\
\hline \multirow{2}{*}{ Smoking } & \multirow{2}{*}{$1.105(<0.001)$} & $\begin{array}{c}\text { Yes } \\
(\mathrm{N}=133)\end{array}$ & $\begin{array}{c}0.909 \\
(0.971) \\
\end{array}$ & $\begin{array}{c}0.292 \\
(0.830) \\
\end{array}$ & $\begin{array}{c}0.123 \\
(0.714) \\
\end{array}$ \\
\hline & & $\begin{array}{c}\text { No } \\
(\mathrm{N}=56)\end{array}$ & $\begin{array}{c}0.570 \\
(0.804)\end{array}$ & $\begin{array}{c}0.722 \\
(0.883)\end{array}$ & $\begin{array}{l}0.072 * \\
(0.531)\end{array}$ \\
\hline \multirow{2}{*}{ Alcohol addiction } & \multirow{2}{*}{$22.387(0.995)$} & $\begin{array}{c}\text { Yes } \\
(\mathrm{N}=130)\end{array}$ & $\begin{array}{c}0.418 \\
(0.806)\end{array}$ & $\begin{array}{c}0.817 \\
(0.961)\end{array}$ & $\begin{array}{c}0.034 \\
(0.615)\end{array}$ \\
\hline & & $\begin{array}{c}\text { No } \\
(\mathrm{N}=59)\end{array}$ & $\begin{array}{c}0.740 \\
(1.113)\end{array}$ & $\begin{array}{c}0.588 \\
(0.883)\end{array}$ & $\begin{array}{c}0.332 \\
(0.763)\end{array}$ \\
\hline \multirow{2}{*}{$\begin{array}{l}\text { Familial psycho- } \\
\text { pathology }\end{array}$} & \multirow{2}{*}{$1.384(<0.001)$} & $\begin{array}{c}\text { Yes } \\
(\mathrm{N}=68)\end{array}$ & $\begin{array}{c}0.826 \\
(0.932)\end{array}$ & $\begin{array}{c}0.919 \\
(1.022)\end{array}$ & $\begin{array}{c}0.025 \\
(0.512)\end{array}$ \\
\hline & & $\begin{array}{c}\text { No } \\
(\mathrm{N}=121)\end{array}$ & $\begin{array}{c}0.603 \\
(0.870)\end{array}$ & $\begin{array}{c}0.456 \\
(0.877)\end{array}$ & $\begin{array}{c}0.301 \\
(0.800)\end{array}$ \\
\hline \multirow{3}{*}{ Income level } & \multirow{3}{*}{$0.063(0.940)$} & $\begin{array}{c}\text { Low } \\
(\mathrm{N}=26)\end{array}$ & $\begin{array}{c}0.838 \\
(1.096)\end{array}$ & $\begin{array}{c}0.370 \\
(1.335)\end{array}$ & $\begin{array}{c}0.183 \\
(0.555)\end{array}$ \\
\hline & & $\begin{array}{l}\text { Average } \\
(\mathrm{N}=133)\end{array}$ & $\begin{array}{c}0.789 \\
(0.933)\end{array}$ & $\begin{array}{c}0.422 \\
(0.874)\end{array}$ & $\begin{array}{c}0.314 \\
(0.811)\end{array}$ \\
\hline & & $\begin{array}{c}\text { High } \\
(\mathrm{N}=30)\end{array}$ & $\begin{array}{c}0.105 \\
(0.366)\end{array}$ & $\begin{array}{c}0.884 \\
(0.957)\end{array}$ & $\begin{array}{c}0.023 \\
(0.324)\end{array}$ \\
\hline \multirow{2}{*}{$\begin{array}{l}\text { Childhood adversi- } \\
\text { ty }\end{array}$} & \multirow{2}{*}{$-0.448(0.694)$} & $\begin{array}{c}\text { Yes } \\
(\mathrm{N}=26)\end{array}$ & $\begin{array}{c}0.312 \\
(0.572)\end{array}$ & $\begin{array}{c}0.610 \\
(0.850)\end{array}$ & $\begin{array}{c}0.098 \\
(0.461)\end{array}$ \\
\hline & & $\begin{array}{c}\text { No } \\
(\mathrm{N}=163)\end{array}$ & $\begin{array}{c}0.902 \\
(1.032)\end{array}$ & $\begin{array}{c}0.710 \\
(0.913)\end{array}$ & $\begin{array}{l}0.081^{*} \\
(0.664)\end{array}$ \\
\hline \multirow{3}{*}{ Birth order } & \multirow{3}{*}{$0.640(0.008)$} & $\begin{array}{c}1 \\
(\mathrm{~N}=77)\end{array}$ & $\begin{array}{c}0.138 \\
(0.598)\end{array}$ & $\begin{array}{c}0.567 \\
(0.886)\end{array}$ & $\begin{array}{c}0.178 \\
(0.699)\end{array}$ \\
\hline & & $\begin{array}{c}2 \\
(\mathrm{~N}=58)\end{array}$ & $\begin{array}{c}0.216 \\
(1.473)\end{array}$ & $\begin{array}{c}0.684 \\
(0.911)\end{array}$ & $\begin{array}{c}0.421 \\
(0.796)\end{array}$ \\
\hline & & $\begin{array}{c}>3 \\
(\mathrm{~N}=54)\end{array}$ & $\begin{array}{c}0.786 \\
(0.908)\end{array}$ & $\begin{array}{c}0.673 \\
(1.102)\end{array}$ & $\begin{array}{l}0.074 * \\
(0.560)\end{array}$ \\
\hline \multirow{2}{*}{ Family structure } & \multirow{2}{*}{$-0.022(0.984)$} & $\begin{array}{l}\text { Complete family } \\
(\mathrm{N}=150)\end{array}$ & $\begin{array}{c}0.793 \\
(1.071)\end{array}$ & $\begin{array}{c}0.476 \\
(0.838)\end{array}$ & $\begin{array}{l}0.080 * \\
(0.656)\end{array}$ \\
\hline & & $\begin{array}{l}\text { Incomplete family } \\
(\mathrm{N}=39)\end{array}$ & $\begin{array}{c}0.238 \\
(0.581)\end{array}$ & $\begin{array}{c}0.856 \\
(0.952)\end{array}$ & $\begin{array}{c}0.093 \\
(0.531)\end{array}$ \\
\hline
\end{tabular}

Note: P-values (ORs) for additive logistic regression model are reported except for *, which stands for dominant regression model. Statistically significant logistic regression models $(\mathrm{P}<0.05)$ are shown in bold. Dashes stand for low sample size groups, which could cause type I and II errors. **Minor/major alleles of examined SNPs are indicated. 
Linkage disequilibrium testing revealed a high LD between OXTR rs2228485 and rs53576 in the total sample, as well as in groups differing in sex and ethnicity (D' > 0.845). We observed the following haplotype frequencies in criminal offenders group and in population controls: $G A(0.014$ and 0.014$)$, $A A$ (0.420 and 0.439), $G G$ (0.166 and 0.224), and $A G$ (0.400 and 0.323), respectively. A statistically significant increase in the frequency of OXTR AG haplotype (based on rs2228485 and rs53576) was observed in a group of criminal offenders compared to control group $\left(\mathrm{P}=0.047 ; \mathrm{P}_{\text {perm }}=0.049 ; \beta=3.94\right.$; $\mathrm{OR}=1.38)$ (Fig.). The following analysis of haplotype-by-environment interactions indicated that the inclusion of such environmental parameters as sex $\left(\mathrm{P}=0.040 ; \mathrm{P}_{\text {perm }}=0.037\right.$; $\beta=4.22 ; \mathrm{OR}=1.40)$, ethnicity $(\mathrm{P}=0.030$; $\mathrm{P}_{\text {perm }}=0.026 ; \beta=4.71 ; \mathrm{OR}=1.43$ ) and familial history of psychopathologies $(\mathrm{P}=0.049$; $\mathrm{P}_{\text {perm }}=0.046 ; \beta=3.88$; OR $\left.=1.41\right)$ demonstrated a slightly higher level of predicting enhanced aggression in $O X T R A G$ haplotype carriers. Moreover, higher education level demonstrated a significant positive effect on association of $O X T R G G$ haplotype and a reduced risk of demonstrating antisocial behavior $\left(\mathrm{P}=0.019 ; \mathrm{P}_{\text {perm }}=0.027 ; \beta=5.46\right.$; $\mathrm{OR}=0.57)$.

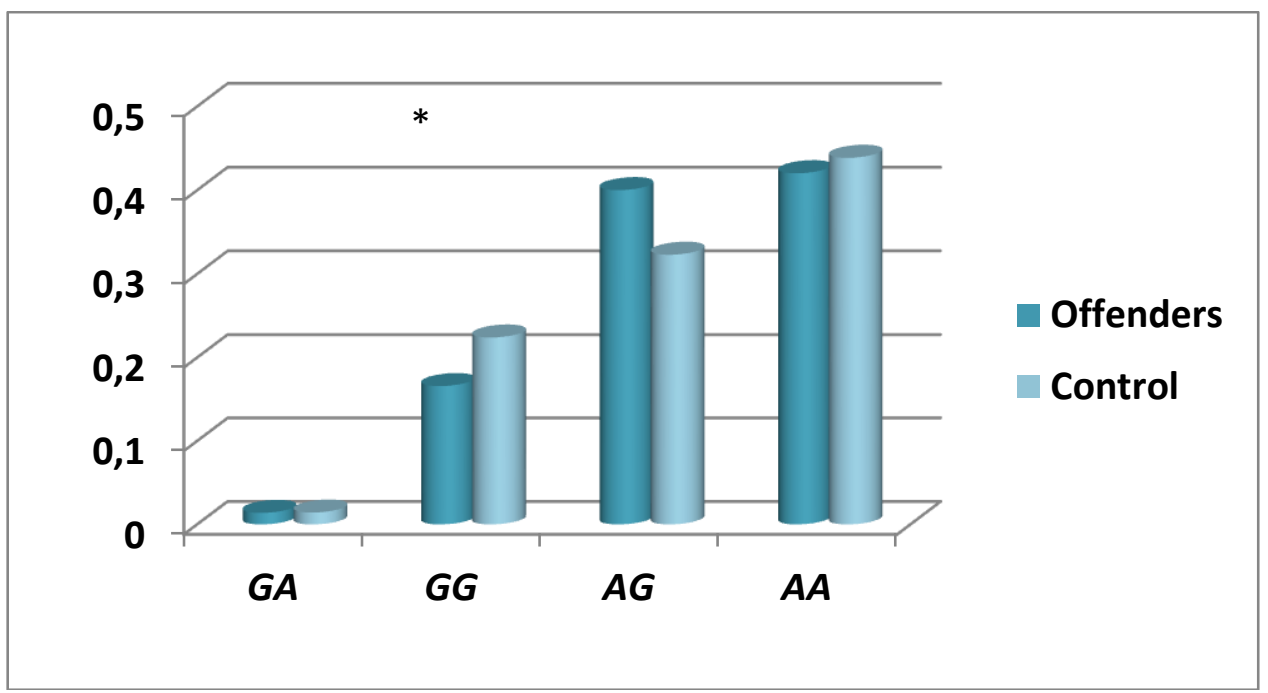

Fig. The distribution of $O X T R$ haplotype frequencies (based on rs2228485 and rs53576) in the total sample. The effect of OXTR AG haplotype is shown with an asterisk $(\mathrm{P}<0.05)$.

In summary, in the present study we observed that allelic variant in the OXTR rs2228485 was a predictor of antisocial behavior in the total sample and in the subgroups stratified by the presence of severe somatic disorders, alcohol addiction, familial history of psychopathologies and income level. Previously Lucht et al. (2009) demonstrated the effect of this SNP on individual variance in emotional loneliness, hostility, distress, irritability, nervousness, which was associated with OXTR GGG haplotype (rs53576/rs2254298/rs2228485) compared to carriers of GGA haplotype [4]. At the same time, a significant increase in positive symptoms such as interest, activity, and excitement (assessed via the Positive and Negative Affect Schedule) was relevant for carriers of OXTR $A G A$ (rs53576/rs2254298/rs2228485) haplotype compared to those bearing $G A G, G A A$, $G G G$, and $G G A$ haplotypes [4]. Based on the mentioned haplotype frequency distribution it can be suggested that $r s 2228485$ has a higher impact on developing negative symptoms (such as aggression and irritability), while rs53576 variant is more significant for the positive social behavior. From the evolutionary point of view, rs2228485 $A$-allele has been fixed in one great ape species (Pan paniscus, chimpanzee), while it was eliminated in another one (Pan troglodytes, bonobo) [17]. Such $A$-allele accumulation was sug- 
gested to be attributed to male-male relations in chimpanzee compared to male-female bonds that are characteristic for bonobos. Therefore, our findings also indicate the accumulation of aggressive traits in humans related to the presence of rs2228485 A-allele.

The rs2228485 represents a synonymous substitution in the exon 3 of the OXTR gene, which is probably involved in splicing and regulates for mRNA stability [16] probably due to its location in one of $\mathrm{CpG}$ islands. Although no functional studies, which can clarify the allelic effect of rs2228485 on OXTR gene methylation, have been published to date, the development of antisocial behavior, which manifest under unfavorable adversity, may be partially caused by the differences in the OXTR gene methylation [3, 10, 38]. The impact of another examined SNP (rs53576) on epigenetic regulation of OXTR expression was reported. To be more precise, reduced $O X T R$ methylation was related to the OXTR rs53576 GG-genotype [10]. Another epigenetic research also indicated that $O X T R$ rs53576 $G G$-genotype might modulate the positive effect of exogenous oxytocin on mentalizing, attention and reward processing during social interactions [38]. In addition, maternal addiction, criminal behavior and psychopathology during pregnancy may be attributed to the offspring's OXTR hypermethylation and an enhanced risk for developing callous-unemotional traits later in life [39]. Considering that rs2228485 and rs53576 were shown to be in a high linkage disequilibrium, and rs53576 $G$-allele correlates with less methylation of the OXTR gene [21], based on the observation of $A A / G G$ haplotypic phase we can assume the possible correlation of rs2228485 $G$-allele with higher $O X T R$ gene expression. According to the reported findings, this allele (under haplotype-based tests) was associated with a decreased risk of manifesting aggression, which is congruent to the relation of lower oxytocin level in CSF and enhanced antisocial behavior [7].

Since we reported an opposite effect of $O X T R$-based (rs2228485, rs53576) $A G$ and $G G$ haplotypes on an increased and decreased risk for developing aggressive behavior, re- spectively, which is additionally affected by differences in education level, it can be supposed that rs2228485 has a higher impact to predict antisocial behavior compared to the rs53576. In turn, we showed that rs53576 Gallele (under haplotype-based effect) was associated with a lower risk for developing violent criminal behavior under the conditions of favorable environment (i.e. higher level of education). Multiple findings indicate the association of rs53576 A-allele with higher antisocial traits, and $G$-allele with enhanced prosocial behavior. Namely, a significant association of rs53576 $A A$-genotype and physical aggression and hostility was obtained in boys compared to other genotype carriers as a response to stressful life events [19]. In agreement with the above mentioned data other scientists demonstrated the relation of rs53576 $G G$-genotype to higher social support and empathy, which was specific to socioeconomic status [20]. It seems that the development of antisocial behavior and enhanced aggression may be relevant to the formation of callous unemotional traits in childhood caused by unfavorable environments. For instance, the frequency of rs53576 A-allele was higher in children with enhanced score on callous-unemotional traits and stressful lifetime conditions than of $G G$-genotype [34]. Therefore, in our study we reported the association of rs53576 $G$-allele and a reduced risk of manifesting antisocial behavior in those with high level of education, representing a favorable environmental condition, which at some extent is congruent with published gene-byenvironment interactions. Moreover, such unfavorable conditions as maternal high verbal aggression early in childhood may have a detrimental effect on individual's internalizing problems later in life [35]. Interestingly, in the focus of child-parent relationship qualities in the Finnish cohort consisting of two parent generations there was a pronounced positive effect of maternal emotional warmth (G1 generation) on the transmission of the same pattern of rearing of their children ( $\mathrm{G} 2$ generation) on their offspring (G3 generation) only under the condition of OXTR rs53576 AA/AGgenotypes [40]. Therefore, a reduced oxyto- 
cin-related functioning may benefit from the positive parental rearing. And vice versa, more supportive social behavior in midlife was observed in rs53576 GG-carriers compared to $A$-allele carriers under the history of unfavorable conditions (experience of higher level of emotional abuse in childhood) [37].

Although in the present study we succeed to observe a male-specific effect of OXTR rs53576 $G$-allele on a lower risk of developing outward-directed aggression under favorable environment (since the main proportion of our examined sample included men), it seems that this observation can be extrapolated to women, as was shown by other research groups [41]. In the longitudinal sample of females, the presence of at least one copy of the rs53576 $A$-allele and greater emotional dysregulation predicted a higher risk of developing antisocial personality disorder [41].

According to the results of haplotypebased association with $\mathrm{AB}$ revealed in the present study, there was a significant effect of controlling for ethnicity in logistic regression model. This observation seems to be congruent with the results of a recent meta-analysis ( $\mathrm{N}=8933,18-98$ years), which revealed ethnicity-specific differential effects of rs53576 $G$-allele on higher cognitive empathy in Asian cohorts and affective empathy in European cohorts [42]. Interestingly, the association of $G G$-homozygotes on improved empathy was evident only in young to middle-aged adults, thus indicating the necessity to control for both ethnocultural effects and advanced age, while analyzing $O X T R$-related phenotypes. Nevertheless, another research group demonstrated a homogenous pattern of association of the OXTR rs53576 GG variant and higher altruism even in traditional societies of East Africa [43].

Although in the present study we didn't observe the association of the examined SNPs and aggression depending on the type of $\mathrm{AB}$ (proactive vs. reactive aggression), there is some evidence of interaction between OXTR variants and delinquency in peers on proactive aggression in adolescents [18]. In turn, the presence of empathy (which oppositely correlates with antisocial behavior) in rs53576 $G G$-carriers was associated with a higher risk for manifesting a reactive type of aggressive behavior under the conditions of distress compared to individuals with rs53576 A-allele [44]. Unfortunately, we were unable to control for deviant peer affiliation due to the lack of such data in our group of offenders.

In the present study we also indicated the effect of $A V P R 1 B$ rs33911258 $G$-allele on a decreased risk for manifesting antisocial behavior, while $A A$-genotype was associated with an increased risk. According to our previous findings [45], rs33911258 $A$-allele (due to haplotype-based effect) was more frequent in mentally healthy young adults, who reported lower self-transcendence. Since lower selftranscendence correlates with worse empathy [46], it seems that the results from our both studies are in one direction, thus providing evidence for a positive selection of rs33911258 $G$-allele to facilitate transmission of empathy-related traits. Other scientific groups also point to the involvement of $A V P R 1 B$ gene variants in developing aggression even in childhood [23]. Moreover, our findings seem to be in line with evolutionary data obtained in Platyrrhini [47], which indicated that $4 \%$ of $A V P R I B$ sites may be under positive selection for accumulation of certain prosocial traits. In addition, the same research group reported that a positive selection related to domestication was attributed to the fixation of specific sites in the $A V P R I B$ gene [29]. Despite scientific interest toward the $A V P R I B$ gene variants and prosocial behavior, we have demonstrated the effect of rs33911258, which is located in the promoter region of the $A V P R I B$ gene and, hence, is probably responsible for differential gene expression, on severe type of antisocial behavior for the first time.

Conclusion. In conclusion, reported findings indicate the involvement of several gene variants of HPA-axis together with environmental parameters in probable modulation of OXTR and AVPRIB gene methylation, thus causing a weakened self-control and violent antisocial behavior. From the other side, the existence of certain gene variants, which were 
reported to be related to aggressive behavior in previous research, may demonstrate the opposite effect under adverse environments, which evidence in the significant modulating role of environmental factors in genetic associations with antisocial traits.

Together with the impact of genotypeby-environment interaction, we succeeded to determine a significant modulating effect of certain environmental parameters (i.e. familial history of psychopathologies and education level) on haplotype-based association with manifesting aggression. The data obtained clarified the possible shift in the OXTR allele effect on antisocial behavior under favorable and adverse environments.

It should be noted that the present study continues our previous research, which suggests a significant role of child-parent relationships in modulating the association of OXTR gene variants and affective-related traits in non-criminal young adults $[16,32]$. In turn, identification of certain gene-byenvironment interactions attributing to $\mathrm{AB}$ liability may facilitate the future research of exogenous treatment with neuropeptides to eliminate the aggression. Such studies have already reported the successful oxytocin administration aimed to control for antisocial traits depending on the genetic background of individual $O X T R$ genotypes [48].

\section{Financial support}

The study was supported by the State Contract of the Ministry of Science and Education of RF (№AAAA-A21-121011990119-1). DNA samples for the study were provided by the IBG UFRC RAS collection "Collection of human biological materials" developed within the project № 007-030164/2.

\section{Conflict of interests}

The authors have no conflict of interest to declare.

\section{References}

1. Davydova JD, Litvinov SS, Enikeeva $\mathrm{RF}$, et al. Recent advances in genetics of aggressive behavior. Russian Journal of Genetics: Ap- plied Research. 2018;22(6):716-725. DOI: https://doi.org/10.18699/VJ18.415

2. Portal of legal statistics of the Prosecutor General's Office of the Russian Federation: crime rates in Russia [Internet]. Russia: the Prosecutor General's Office of the Russian Federation; 2021 [cited 2021 Apr 29]. Available from: http://www.crimestat.ru

3. Mustafin RN, Khusnutdinova EK, Kazantseva AV, et al. Epigenetics of aggressive behavior. Russian Journal of Genetics. 2019;55(9):1051-1060. DOI: https://doi.org/10.1134/S1022795419090096

4. Lucht MJ, Barnow S, Sonnenfeld C, et al. Associations between the oxytocin receptor gene (OXTR) and affect, loneliness and intelligence in normal subjects. Progress in NeuroPsychopharmacology and Biological Psychiatry. 2009;33(5):860-866.

DOI: https://doi.org/10.1016/j.pnpbp.2009.04.004

5. Tan O, Musullulu H, Raymond JS, et al. Oxytocin and vasopressin inhibit hyperaggressive behaviour in socially isolated mice. Neuropharmacology. 2019;156:107573. DOI: https://doi.org/10.1016/j.neuropharm.2019.03.016

6. Witchey SK, Stevenson EL, Caldwell HK. Genotypic differences in intruder-evoked immediate early gene activation in male, but not female, vasopressin $1 \mathrm{~b}$ receptor knockout mice. BMC Neuroscience. 2016;17(1):75. DOI: https://doi.org/10.1186/s12868-016-0310-7

7. Lee R, Ferris C, Van de Kar LD, et al. Cerebrospinal fluid oxytocin, life history of aggression, and personality disorder. Psychoneuroendocrinology. 2009;34(10):1567-1573. DOI: https://doi.org/10.1016/j.psyneuen.2009.06.002.

8. Caldwell HK, Aulino EA, Rodriguez KM, et al. Social Context, Stress, Neuropsychiatric Disorders, and the Vasopressin 1b Receptor. Frontiers in Neuroscience. 2017;11:567. DOI: https://doi.org/10.3389/fnins.2017.00567

9. Acosta H, Tuulari JJ, Kantojärvi K, et al. A variation in the infant oxytocin receptor gene modulates infant hippocampal volumes in association with sex and prenatal maternal anxiety. Psychiatry Research - Neuroimaging. 2021;307:111207. DOI: https://doi.org/10.1016/j.pscychresns.2020.11120 7

10. Womersley JS, Hemmings SMJ, Ziegler $\mathrm{C}$, et al. Childhood emotional neglect and oxytocin receptor variants: Association with limbic brain volumes. World Journal of Biological Psy- 
chiatry. 2020;21(7):513-528. DOI: https://doi.org/ 10.1080/15622975.2019.1584331

11. Parris MS, Grunebaum MF, Galfalvy $\mathrm{HC}$, et al. Attempted suicide and oxytocin-related gene polymorphisms. Journal of Affective Disorders. $2018 ; 238: 62-68 . \quad$ DOI: https://doi.org/10.1016/j.jad.2018.05.022

12. Zhang M, Liu N, Chen H, et al. Oxytocin receptor gene, childhood maltreatment and borderline personality disorder features among male inmates in China. BMC Psychiatry. 2020;20(1):332. https://doi.org/10.1186/s12888-020-02710-0

13. Oksman E, Rosenström T, Hintsanen M, et al. A Longitudinal Multilevel Study of the "Social" Genotype and Diversity of the Phenotype. Frontiers in Psychology. 2018;9:2034. DOI: https://doi.org/10.3389/fpsyg.2018.02034

14. Meixner F, Montag C, Herbert C. Affective Language, Interpretation Bias and Its Molecular Genetic Variations: Exploring the Relationship Between Genetic Variations of the OXTR Gene (rs53576 and rs2268498) and the Emotional Evaluation of Words Related to the Self or the Other. Frontiers in Psychology. 2019;10:68. DOI: https://doi.org/10.3389/fpsyg.2019.00068

15. Jokinen J, Chatzittofis A, Hellström C, et al. Low CSF oxytocin reflects high intent in suicide attempters. Psychoneuroendocrinology. 2012;37(4):482-490.

DOI: https://doi.org/10.1016/j.psyneuen.2011.07.016

16. Davydova YD, Kazantseva AV, Enikeeva RF, et al. The role of oxytocin receptor (OXTR) gene polymorphisms in the development of aggressive behavior in healthy individuals. Russian Journal of Genetics. 2020;56(9):11291138. https://doi.org/10.1134/S1022795420090057

17. Staes N, Guevara EE, Helsen P, et al. The Pan social brain: An evolutionary history of neurochemical receptor genes and their potential impact on sociocognitive differences. Journal of Human Evolution. 2021;152:102949. DOI: https://doi.org/10.1016/j.jhevol.2021.102949

18. Fragkaki I, Cima M, Verhagen $M$, et al. Oxytocin receptor gene (OXTR) and deviant peer affiliation: A gene-environment interaction in adolescent antisocial behavior. Journal of Youth and Adolescence. 2019;48(1):86-101. DOI: https://doi.org/10.1007/s10964-018-0939-x

19. Shao D, Zhang HH, Long ZT, et al. Effect of the interaction between oxytocin receptor gene polymorphism (rs53576) and stressful life events on aggression in Chinese Han adolescents.
Psychoneuroendocrinology. 2018; 96:35-41. DOI: https://doi.org/10.1016/j.psyneuen.2018.06.002

20. Sun R, Vuillier L, Hui BPH, et al. Caring helps: Trait empathy is related to better coping strategies and differs in the poor versus the rich. PLoS ONE. 2019;14(3):e0213142. DOI: https://doi.org/10.1371/journal.pone.0213142

21. Chagnon $\mathrm{YC}$, Potvin $\mathrm{O}$, Hudon $\mathrm{C}$, et al. DNA methylation and single nucleotide variants in the brain-derived neurotrophic factor (BDNF) and oxytocin receptor (OXTR) genes are associated with anxiety/depression in older women. Frontiers in Genetics. 2015;6:230. DOI: https://doi.org/10.3389/fgene.2015.00230

22. Tost H, Kolachana B, Hakimi S, et al. A common allele in the oxytocin receptor gene (OXTR) impacts prosocial temperament and human hypothalamic-limbic structure and function. Proceedings of the National Academy of Sciences of the United States of America. 2010;107(31):13936-13941. DOI: https://doi.org/10.1073/pnas.1003296107

23. Zai CC, Muir KE, Nowrouzi B, et al. Possible genetic association between vasopressin receptor $1 \mathrm{~B}$ and child aggression. Psychiatry Research. 2012;200(2-3):784-788. DOI: https://doi.org/10.1016/j.psychres.2012.07.031

24. Poore HE, Waldman ID. The Association of Oxytocin Receptor Gene (OXTR) Polymorphisms with Antisocial Behavior: A Metaanalysis. Behavior Genetics. 2020;50(3):161-173. DOI: https://doi.org/10.1007/s10519-020-09996-6

25. Malhi GS, Das P, Outhred T, et al. Interactions of OXTR rs53576 and emotional trauma on hippocampal volumes and perceived social support in adolescent girls. Psychoneuroendocrinology. 2020;115:104635. DOI: https://doi.org/10.1016/j.psyneuen.2020.104635

26. Waller R, Corral-Frías NS, Vannucci $\mathrm{B}$, et al. An oxytocin receptor polymorphism predicts amygdala reactivity and antisocial behavior in men. Social Cognitive and Affective Neuroscience. $\quad 2016 ; 11(8): 1218-26 . \quad$ DOI: https://doi.org/10.1093/scan/nsw042

27. Wang J, Zhang Y, Zhu D, et al. A common variant in OXTR rs53576 impacts topological patterns of brain functional networks. European Child and Adolescent Psychiatry. 2020;29(7):993-1002. DOI: https://doi.org/10.1007/s00787-019-01414-5

28. Aghajani M, Klapwijk ET, Colins OF, et al. Interactions Between Oxytocin Receptor Gene Methylation and Callous-Unemotional Traits Impact Socioaffective Brain Systems in 
Conduct-Disordered Offenders. Biological Psychiatry: Cognitive Neuroscience and Neuroimaging. 2018;3(4):379-391. DOI: https://doi.org/10.1016/j.bpsc.2017.12.010

29. Fam BSO, Paré P, Felkl AB, et al. Oxytocin and arginine vasopressin systems in the domestication process. Genetics and Molecular Biology. 2018;41(1 suppl 1):235-242. DOI: https://doi.org/10.1590/1678-4685-GMB-20170069

30. Champagne-Jorgensen K, Mian MF, Kay S, et al. Prenatal low-dose penicillin results in long-term sex-specific changes to murine behaviour, immune regulation, and gut microbiota. Brain, Behavior, and Immunity. 2020;84:154-163. DOI: https://doi.org/10.1016/j.bbi.2019.11.020

31. Wu N, Shang S, Su Y. The arginine vasopressin $\mathrm{V} 1 \mathrm{~b}$ receptor gene and prosociality: Mediation role of emotional empathy. PsyCh Journal. 2015;4(3):160-5. DOI: https://doi.org/10.1002/pchj.102

32. Kazantseva A, Davydova Yu, Enikeeva R, et al. AVPR1A main effect and OXTRby-environment interplay in individual differences in depression level. Heliyon. 2020;6(10):e05240. DOI: https://doi.org/10.1016/j.heliyon.2020.e05240

33. Madlon-Kay S, Montague MJ, Brent LJN, et al. Weak effects of common genetic variation in oxytocin and vasopressin receptor genes on rhesus macaque social behavior. American Journal of Primatology. 2018;80(10):e22873. DOI: https://doi.org/10.1002/ajp.22873

34. Ezpeleta L, Penelo E, de la Osa N, et al. Association of OXTR rs53576 with the Developmental Trajectories of Callous-Unemotional Traits and Stressful Life Events in 3- to 9-YearOld Community Children. Journal of Abnormal Child Psychology. 2019;47(10):1651-1662. DOI: https://doi.org/10.1007/s10802-019-00548-z

35. Smarius LJCA, Strieder TGA, Doreleijers TAH, et al. Maternal verbal aggression in early infancy and child's internalizing symptoms: interaction by common oxytocin polymorphisms. European Archives of Psychiatry and Clinical Neuroscience. 2020;270(5):541-551. DOI: https://doi.org/10.1007/s00406-019-01013-0

36. Liu J, Shang S, Pei M, et al. Influence of Two Single-Nucleotide Polymorphisms of the Oxytocin Receptor Gene (OXTR) on Empathy: the Mediation Role of a Primary Emotion, CARE. Journal of Molecular Neuroscience. 2021;71(2):252-261. DOI: https://doi.org/10.1007/s12031-020-01644-2
37. Ebbert AM, Infurna FJ, Luthar SS, et al. Examining the link between emotional childhood abuse and social relationships in midlife: The moderating role of the oxytocin receptor gene. Child Abuse and Neglect. 2019;98:104151. DOI:

https://doi.org/10.1016/j.chiabu.2019.104151

38. Chen X, Nishitani S, Haroon E, et al. OXTR methylation modulates exogenous oxytocin effects on human brain activity during social interaction. Genes, Brain and Behavior. 2020;19(1):e12555. DOI: https://doi.org/10.1111/gbb.12555

39. Cecil CA, Lysenko LJ, Jaffee SR, et al. Environmental risk, Oxytocin Receptor Gene (OXTR) methylation and youth callousunemotional traits: a 13-year longitudinal study. Molecular Psychiatry. 2014;19(10):1071-1077. DOI: https://doi.org/10.1038/mp.2014.95

40. Savelieva K, Hintsanen M, Dobewall $\mathrm{H}$, et al. The role of oxytocinergic genes in the intergenerational transmission of parent-child relationship qualities. Hormones and Behavior. 2019;114:104540. DOI: https://doi.org/10.1016/j.yhbeh.2019.06.004

41. Byrd AL, Tung I, Manuck SD, et al. An interaction between early threat exposure and the oxytocin receptor in females: Disorderspecific versus general risk for psychopathology and social-emotional mediators. Development and Psychopathology. 2020:1-16. DOI: https://doi.org/10.1017/S0954579420000462

42. Chander RJ, Mather KA, Cleary R, et al. The influence of rs53576 polymorphism in the oxytocin receptor (OXTR) gene on empathy in healthy adults by subtype and ethnicity: a systematic review and meta-analysis. Reviews in the Neurosciences. 2021. DOI: https://doi.org/10.1515/revneuro-2021-0038

43. Butovskaya ML, Karelin DV, Dronova DA, et al. Strategies for Sharing Limited Resources among Children and Adolescents in Three Traditional Societies of East Africa: Sociocultural and Genetic Factors. Doklady Biological Sciences. 2020;494(1):219-224. DOI: https://doi.org/10.1134/S001249662004002X

44. Buffone AE, Poulin MJ. Empathy, target distress, and neurohormone genes interact to predict aggression for others-even without provocation. Personality and Social Psychology Bulletin. 2014;40(11):1406-1422. DOI: https://doi.org/10.1177/0146167214549320

45. Kazantseva AV, Kutlumbetova YY, Malykh SB, et al. Arginine-vasopressin receptor 
gene (AVPR1A, AVPR1B) polymorphisms and their relation to personality traits. Russian Journal of Genetics. 2014;50(3):298-307. DOI: https://doi.org/10.7868/S0016675814030047

46. Kazantseva AV, Malykh SB, Khusnutdinova EK. Molecular-genetic studies of personality traits: from candidate genes to genome-wide association studies. In: Malykh SB, Kovas YV, Gaysina DA, editors. Behavior genetics: children development and education. Tomsk: Tomsk State University; 2016:178-209.

47. Fam BSO, Reales G, Vargas-Pinilla P, et al. AVPR1b variation and the emergence of adaptive phenotypes in Platyrrhini primates. American Journal of Primatology. 2019;81(8):e23028. $\quad$ DOI: https://doi.org/10.1002/ajp.23028

48. Zhao W, Luo R, Sindermann C, et al. Oxytocin modulation of self-referential processing is partly replicable and sensitive to oxytocin receptor genotype. Progress in NeuroPsychopharmacology and Biological Psychiatry. 2020;96:109734. DOI: https://doi.org/10.1016/j.pnpbp.2019.109734

Received 29 April 2021

Revised 8 June 2021

Accepted 16 June 2021

\section{Information about the authors}

Anastasiya V. Kazantseva, Cand. Sci. (Biology), Senior Researcher, Institute of Biochemistry and Genetics, Subdivision of the Ufa Federal Research Centre of the Russian Academy of Sciences; Associate Professor at the Department of Molecular Technologies, Ufa State Petroleum Technological University, Ufa, Russia, E-mail: Kazantsa@mail.ru, ORCID: https://orcid.org/00000002-3744-8058.
Julia D. Davydova, Research Associate, Postgraduate Student in scientific specialty 03.02.07 Genetics, Institute of Biochemistry and Genetics, Subdivision of the Ufa Federal Research Centre of the Russian Academy of Sciences, Ufa, Russia, E-mail: Julia.dmitrievna@list.ru, ORCID: https://orcid.org/0000-0003-3508-4710.

Renata F. Enikeeva, Cand. Sci. (Biology), PostDoctoral Fellow, Institute of Biochemistry and Genetics, Subdivision of the Ufa Federal Research Centre of the Russian Academy of Sciences, Ufa, Russia, E-mail: enikeevarf@gmail.com, ORCID: https://orcid.org/0000-0002-4301-5283.

Rinat G. Valinurov, Doct. Sci. (Medicine), Professor, Bashkir State Medical University, Ufa, Russia, E-mail: valinurov_rkpb@mail.ru, ORCID: https://orcid.org/0000-0002-7284-0530.

Anna E. Gareeva, Cand. Sci. (Medicine), Doct. Sci. (Biology), Senior Researcher, Institute of Biochemistry and Genetics, Subdivision of the Ufa Federal Research Centre of the Russian Academy of Sciences, Ufa, Russia, E-mail: annagareeva@yandex.ru, ORCID: https://orcid.org/0000-0003-0254-3917.

Natalya N. Khusnutdinova, Researcher, Institute of Biochemistry and Genetics, Subdivision of the Ufa Federal Research Centre of the Russian Academy of Sciences, Ufa, Russia, E-mail: KhusnutdinovaNN@mail.ru, ORCID: https://orcid.org/0000-0002-9047-9224.

Elza K. Khusnutdinova, Doct. Sci. (Biology), Professor, Corresponding Member of RAE, Director of the Institute of Biochemistry and Genetics, Subdivision of the Ufa Federal Research Centre of the Russian Academy of Sciences, Ufa, Russia, Email: $\quad$ Elzakh@mail.ru, ORCID: https://orcid.org/0000-0003-2987-3334. 